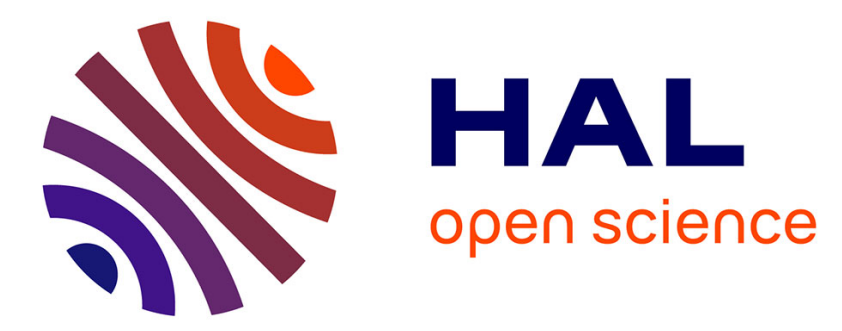

\title{
Geochemistry of three contrasting British peatlands: Complex patterns of cation availability and implications for microbial metabolism
}

Sébastien Gogo, T.G. Shreeve, D.M.E. Pearce

\section{To cite this version:}

Sébastien Gogo, T.G. Shreeve, D.M.E. Pearce. Geochemistry of three contrasting British peatlands: Complex patterns of cation availability and implications for microbial metabolism. Geoderma, 2010, 158 (3-4), pp.207-215. 10.1016/j.geoderma.2010.04.031 . insu-00842188

\section{HAL Id: insu-00842188}

https://hal-insu.archives-ouvertes.fr/insu-00842188

Submitted on 8 Jul 2013

HAL is a multi-disciplinary open access archive for the deposit and dissemination of scientific research documents, whether they are published or not. The documents may come from teaching and research institutions in France or abroad, or from public or private research centers.
L'archive ouverte pluridisciplinaire HAL, est destinée au dépôt et à la diffusion de documents scientifiques de niveau recherche, publiés ou non, émanant des établissements d'enseignement et de recherche français ou étrangers, des laboratoires publics ou privés. 
Geochemistry of three contrasting British peatlands: complex patterns of cation availability and implication for exo-enzymes inhibition

S. Gogo ${ }^{1}$, T.G. Shreeve and D. M. E. Pearce*

School of Life Sciences, Oxford Brookes University

Gipsy Lane Campus, Headington

OX3 OBP Oxford

United Kingdom

* Corresponding author. Tel.: +44 1865 483965; fax: +44 1865483242.

E-mail address: dpearce@brookes.ac.uk (D. M. E. Pearce).

1 Present address: Institut des Sciences de la Terre d'Orléans-Tours, Université d'OrléansUniversité de Tours-CNRS Bâtiment ISTE, 45000 Orléans, France. 


\begin{abstract}
Cation availability in peat may limit $\mathrm{CH}_{4}$ production and microbial activity and thereby impact rates of organic matter accumulation and the chemical character of the peat. We quantify total, soluble, and exchangeable cation concentrations, Exchange Site Saturation Levels (ESSL) and organic fractions in bog-peat profiles and compare these with fen-peat. Total and soluble cation concentrations are not correlated and these and exchangeable cation concentrations are lower in bog than fen peat. In all sites these vary with depth and the distribution patterns of individual cations are unique. This is explained by variation in ESSL, which is negatively correlated with Cation Exchange Capacity (CEC). Total cation concentrations in bog-peat are higher in the top and bottom fractions than in the middle. Soluble concentrations in surface bog-peat are low, because cations are trapped due to low ESSL. This does not occur in fen-peat, with lower CEC and higher ESSL. CEC is related to total organic matter content, not just to Sphagnum, which has been invoked as the explanatory variable of high CEC in peat bogs. There is a complexity in the mechanisms controlling cation availability in peat and we suggest that total, soluble and exchangeable cation fractions need to be taken into account in studies of cation limitation of microbial activity in organic soils.
\end{abstract}

Keywords: cation exchange capacity; adsorption; decomposition; wetland; organic matter; trace element mobilization. 


\section{Introduction}

Organic matter decay is a key process in peatland functioning (Clymo, 1983). The control of microbial activity is only partly understood, but involves cations (Williams and Crawford, 1984; Gonzalez-Gil et al., 1999; Basiliko and Yavitt, 2001; Thomas and Pearce, 2004), anions (Dise and Verry, 2001; Basiliko and Yavitt, 2001), a carbon source (Martin and Holding, 1978; Thomas and Pearce, 2004), and cation exchange capacity (Thomas and Pearce, 2004) at least. Comparisons between studies, and conclusions about the relative roles of different rate-limiting factors are difficult to draw because different indicators of decay rates, combined with different controlling factors have been investigated. For example, Coulson and Butterfield (1978) used mass loss whereas Yavitt et al. (2005) used $\mathrm{CO}_{2}$ and $\mathrm{CH}_{4}$ production whilst measuring ion concentrations in peat samples and correlating these to microbial activity. Experimental approaches have used anion and cation amendments to peat and measured microbial activities (e.g. Williams and Crawford, 1984; Basiliko and Yavitt, 2001; Thomas and Pearce, 2004). Other cation treatments have also included carbon sources (Martin and Holding 1978) and mineral nutrients such as $\mathrm{N}$ and P (Williams and Crawford, 1984). Cations have also been added with different anions (e.g. Williams and Crawford, 1984; Basiliko and Yavitt, 2001; Thomas and Pearce, 2004), without necessarily factoring out the effects of the anions.

There is further inconsistency about the cation fraction estimated to be available to the microbial community. Soluble and exchangeable cation fractions are those available to plants and microbial communities (Chapin III et al., 2002), but are also linked by geochemical processes to total cation concentration. Basiliko and Yavitt (2001) used soluble cation concentration, Yavitt et al. (2005) used the total content and Martin and Holding (1978) based their arguments on exchangeable cations. The ratios of the different fractions vary within and between sites (Gore and Allen, 1956; Waughman, 1980; Kyziol, 
2002) and are influenced by ion exchange processes. Cations in solutions (ionic form) can react with exchange sites on organic matter or clay material (Tummavuori and Aho, 1980; Summer et al., 1991). The strength of adsorption equal between cations and can be increased by, (1) increased cation valency, (2) smaller hydrated size of the cation, and (3) increase of the strength of the site's negative charge (Miller and Donahue, 1990). Also, Cation Exchange Capacity (CEC) increases with organic matter content (Puustjärvi, 1956) and Sphagnum species, which dominate the partially decomposed bulk and living layer of many northern bogs, have a CEC (Puustjärvi, 1956; Clymo, 1963) which may be higher than any other species (Painter, 1995). Therefore, in studies of the role of cations, the effects of CEC must also be carefully considered.

Previous studies have shown that applied soluble cations can stimulate methanogenic activity in peat (Basiliko and Yavitt, 2001; Thomas and Pearce, 2004; Gogo and Pearce, 2009), and that microorganisms (in planktonic and aggregated states) use nutrients in solution (Teitzel and Parsek, 2003; Hall-Stoodley et al., 2004). The mechanisms of cation stimulation may be via direct nutrient stimulation, and be indirect, via release of limiting cations from exchange site reactions. Cation application can also alter carbon availability, as positively charged molecules, for example exo-enzymes, can be bound to exchange sites (Painter, 1995). CEC can play an important role in the occurrence and solubility of nutrients through the amount of cation exchange sites and their level of saturation. If exchange sites are in excess compared to cations, there remain sites available to inhibit exo-enzymes. Understanding the state of cations in peat and how the state of individual elements varies in relation to internal and external mechanisms is important to understanding the control of decay processes and the role of peatlands to act as carbon sinks or sources. 
Here, we quantify cation concentrations in different fractions from three sites of differing CEC. We examine the interaction of cations with the CEC of peat to demonstrate the dynamic nature of cation availability in soluble form and further demonstrate variation in soluble to total cation concentration in relation to CEC.

\section{Materials and methods}

Study sites, collection and preparation of samples

Peat cores were collected from each of three sites with a Russian or "D shape"corer $(50 \mathrm{~cm}$ long; Jowsey, 1966) in January 2003. The first site, Ellergower Moss, is an undisturbed raised bog approximatively $6 \mathrm{~m}$ deep in its centre, situated near New Galloway, south-west Scotland. The surface is dominated by Sphagnum capillifolium, S. papillosum and $S$. cuspidatum and the bulk of the peat comprises partially decomposed Sphagnum. Cores were taken close to the centre of the bog in an area dominated by Sphagnum papillosum. The second site, Cothill Fen is a disturbed minerotrophic calcareous fen about $2 \mathrm{~m}$ deep, situated near Oxford, south-central England. It is dominated by Phragmites with Sphagnum species (S. palustre and S. plumulosum) only present in very low abundance. The third site, Snelsmore Valley Mire, near Newbury, south-central England is a transitional valley mire about $2 \mathrm{~m}$ deep. The vegetation is composed predominantly of Sphagnum papillosum, S. palustre and Eriophorum angustifolium.

At each site, cores were taken for each depth; four depths for Cothill and Snelsmore and eleven for Ellergower Moss. In the field, the depths of the profiles were not always the same $( \pm 10 \mathrm{~cm})$. In Cothill and Snelsmore, 3 core depths of $50 \mathrm{~cm}$ long were collected and the deepest depth (when the corer could be pushed no further) noted as $>1.5 \mathrm{~m}$ (Table 1). In Ellergower Moss, 10 core depths of $50 \mathrm{~cm}$ long were collected and the deepest depth (when the corer could be pushed no further) noted as $>5 \mathrm{~m}$ (Table 1). For each site the 
cores were taken within an area of $2 \mathrm{~m}^{2}$. At the time of collection the water table was at the surface of each of the sampling areas. Each $50 \mathrm{~cm}$ core was placed in a sealed airtight bag ( 4 bags in each profiles from the fens and 10 bags for each profile in the gob), and subsequently stored at $5^{\circ} \mathrm{C}$ on the day of arrival at the laboratory for geochemical analysis. As the samples were stored in separated bags, no vertical transport was possible.

Peat pH was measured with a Jenway $3051 \mathrm{pH}$ meter (Jenway Ltd, England). After calibration with solutions at $\mathrm{pH} 4$ and 7 , the probe was directly introduced into the peat samples (25 cm intervals) until a stable $\mathrm{pH}$ measurement was achieved. Prior to analysis, each peat core $(0.5 \mathrm{~m})$ was placed, within $24 \mathrm{~h}$ hours after the collection on the site (to avoid prolonged microbial activity, in a tray and air dried for c.a. 1 week at $21^{\circ} \mathrm{C}$. Samples were weighed daily until they reached a constant weight, when they were ground with a mortar and pestle and passed through a $1 \mathrm{~mm}$ sieve. Four replicates for each depth sample from each site were used for each analysis.

\section{Extraction methods and measurements of cation concentrations}

Four extractions of increasing strength were performed, following the methods of Ure (1991), University of Minnesota (2000), Karam (1993) and Hill and Siegel (1991). These were: water extraction (soluble cations only), ammonium acetate extraction (exchangeable + soluble cations), nitric acid on dry peat extraction (extractable + exchangeable + soluble cations) and nitric acid on ashes extraction (approximating total elements). For the first three extractions $2.5 \mathrm{~g}$ of air-dried peat was placed in a $50 \mathrm{ml}$ centrifuge tube prior to treatment. After extractant addition, mixing and centrifugation the extracted solutions were filtered (Wathman no.4 ash-free cellulose filter paper, 20-25 $\mu \mathrm{m}$, retention of coarse particles and gelatinous precipitates; Wathman, Maidstone, UK) into $50 \mathrm{ml}$ volumetric flasks and made up to $50 \mathrm{ml}$ with deionised water. Reagent blanks were prepared for each 
extraction method following the same methods as for the samples, but excluding the peat. Samples were stored at $5^{\circ} \mathrm{C}(\max .72 \mathrm{~h})$ until analysed with an Inductively Coupled Plasma Atomic Emission Spectrometer (ICPAES; Jobin Yvon JY 70c, Longjumeau, France), against calibrations defined with synthetic multi-element solutions. The elements analysed were $\mathrm{K}, \mathrm{Na}, \mathrm{Mg}, \mathrm{Ca}, \mathrm{Mn}, \mathrm{Fe}, \mathrm{Co}, \mathrm{Ni}, \mathrm{Cu}, \mathrm{Zn}, \mathrm{Al}$ and $\mathrm{Pb}$. The detection limits of the ICPAES were assessed for the six elements potentially present in low concentrations: Mn $\left(0.001 \mathrm{mg} \mathrm{l}^{-1}\right)$, Co $\left(0.001 \mathrm{mg} \mathrm{l}^{-1}\right), \mathrm{Ni}\left(0.002 \mathrm{mg} \mathrm{l}^{-1}\right), \mathrm{Cu}\left(0.002 \mathrm{mg} \mathrm{l}^{-1}\right), \mathrm{Zn}\left(0.002 \mathrm{mg} \mathrm{l}^{-1}\right)$ and $\mathrm{Pb}\left(0.02 \mathrm{mg} \mathrm{l}^{-1}\right)$. The total content of a reference material (peat (Sphagnum) NJV94-2, Swedish University of Agricultural Sciences) was used as a control. The concentrations in $\mu \mathrm{mol} \mathrm{g}^{-1}$ dry or organic matter were calculated as follows:

$$
[\text { Element }]\left(\mu \mathrm{mol} \mathrm{g}^{-1}\right)=\frac{\text { Measure } \times \text { Volume sample }\left(\mu \mathrm{g} \mathrm{l}^{-1} \times \mathrm{ml}\right)}{\text { Mass sample } \times \text { Molar Mass Element }\left(\mathrm{g} \times \mathrm{g} \mathrm{mol}^{-1}\right)}
$$

The cation concentrations from the first three extractions were expressed on an organic matter basis as this is the pool potentially degradable by microbes. To assess the organic content, peat of each depth $(50 \mathrm{~cm}$ intervals $)$ was oven dried $\left(80^{\circ} \mathrm{C}\right)$, and placed in a muffle furnace for $4 \mathrm{~h}$ at $550^{\circ} \mathrm{C}$. The ash was weighed immediately and the percentage of the organic content was calculated as follow:

$\%$ organic content $=[($ oven dry weight - ash weight $) /$ oven dry weight $] \times 100$ The cation concentrations for the "total" content were expressed on a soil dry weight basis as cations from mineral particles as well as those bound to organic matter were measured.

To assess chelating strength, the quotients of water extractable cations to ammonium acetate extractable ones were calculated. Because ammonium acetate extracts only soluble cations and exchangeable K, Na, Mg and Ca (Karam, 1993; University of 
Minnesota, 2000), the analyses of water to ammonium acetate quotient were only conducted on $\mathrm{K}, \mathrm{Na}, \mathrm{Mg}$ and $\mathrm{Ca}$.

Cation Exchange Capacity (CEC) and assessment of Exchange Sites Saturation Level $(E S S L)$

The technique used for this study was the method of displacement of cations by $1 \mathrm{M}$ $\mathrm{NH}_{4} \mathrm{OAc}$ buffered at $\mathrm{pH} 7$ (Karam, 1993). Air-dry peat $(0.5 \mathrm{~g})$ was shaken with $20 \mathrm{ml}$ of $\mathrm{NH}_{4} \mathrm{OAc}$ and centrifuged at $5000 \mathrm{rev} \mathrm{min}^{-1}$ for 15 minutes in a $50 \mathrm{ml}$ centrifuge tube. The supernatant was discarded and the extraction repeated. The sample was then washed twice with $10 \mathrm{ml}$ methanol to remove the remaining ammonium present. Samples were then mixed with $20 \mathrm{ml}$ of $0.5 \mathrm{M} \mathrm{CaCl}_{2}$ to return to solution the ammonium held on the exchange sites, centrifuged at $5000 \mathrm{rev}^{\mathrm{min}}{ }^{-1}$ for 10 minutes and the supernatant poured into a 100 $\mathrm{ml}$ volumetric flask. This extraction was repeated and the volume made up with deionised water to $100 \mathrm{ml}$. The ammonium concentration was finally measured with an ammonium electrode (Jenway 3045 Ion Analyser, Jenway Ltd, England), the assumption being that the amount of $\mathrm{NH}_{4}{ }^{+}$corresponds to the amount of negative charge occupied previously by $\mathrm{K}^{+}$, $\mathrm{Na}^{+}, \mathrm{Mg}^{2+}, \mathrm{Ca}^{2+}$ and $\mathrm{H}^{+}$.

Exchange site saturation levels (ESSL) by macronutrient cations (K, $\mathrm{Na}, \mathrm{Mg}$ and $\mathrm{Ca}$ ), micronutrient cations ( $\mathrm{Mn}, \mathrm{Fe}, \mathrm{Ni}, \mathrm{Co}, \mathrm{Cu}$ and $\mathrm{Zn}$,) and $\mathrm{Al}$ and $\mathrm{Pb}$ are the quotient of ammonium acetate and nitric acid extractable cations versus CEC (modified from Hill and Siegel,1991; each expressed as cmol of positive or negative charge per gram of OM). A value less than 1 represents unsaturated exchange sites, whereas a value greater than 1 represents saturated sites. Ammonium displaces mainly $\mathrm{K}^{+}, \mathrm{Na}^{+}, \mathrm{Mg}^{2+}, \mathrm{Ca}^{2+}$ and $\mathrm{H}^{+}$. Cations (such as $\mathrm{Pb}, \mathrm{Cu}$ and $\mathrm{Al}$ ) strongly bound to organic matter may not be fully displaced by $\mathrm{NH}_{4}{ }^{+}$. Calculating the ESSL with the nitric acid extraction assesses how much 
of these strongly bound cations were not displaced by the ammonium acetate treatment. At the $\mathrm{pH}$ of Ellergower Moss and Snelsmore all cations would have been in their most reduced form, whereas for Cothill cations e.g. Fe, Al and Mn may have been in chemical forms other than ionically bound to exchange sites.

\section{Data analysis}

All experimental designs were one- or two-way ANOVAs. The response variables for all experimental designs were all the soluble and total cations taken separately, the soluble and total sum of positive charge from macro- and micronutrients, soluble to exchangeable quotient (chelating strength) and CEC.

The depth effect on response variables in Ellergower Moss was a one-way ANOVA design. However, because the residuals were normally distributed, but the variances were unequal, the Welch test was performed followed by a Tamhane post-hoc test (SPSS, 2004).

For each response variable, the three sites were compared using the first four depths (max depth of Cothill and Snelsmore $=2 \mathrm{~m}$ ) using a two-way factorial ANOVA (with site and depth as the main effects). The null hypotheses were: a) there are no differences in response variable between sites (pooling depths), b) there are no differences in response variable between depths (pooling sites) and c) there are no interactions between site and depth. When the data did not fulfil the ANOVA assumptions, the Aligned Rank Transformation (ART) method was performed (Richter and Payton, 1999), followed by a post hoc Tukey test, using Statistica (Statsoft, 2001). Because the ART method is nonparametric, the results are presented as medians with ranges.

\section{Results}

Peat $p H$ 
Peat samples from Ellergower Moss ( $\mathrm{pH}$ from 3.6 to 4.4; Table 1) and Snelsmore valley mire ( $\mathrm{pH}$ from 4.2 to 4.6 ) were acidic and hence cations would be in their highest oxidation state (e.g. $\mathrm{Al}^{3+}$ ) and soluble cation concentrations controlled by cation exchange. At such low $\mathrm{pH}$ values other chemical forms are absent. In Cothill some of the cations may be in non-exchangeable forms because of higher $\mathrm{pH}(\mathrm{pH}$ from 5.3 to 6.5).

\section{Cation concentrations in Ellergower Moss}

In Ellergower Moss, the total concentration of each cation changed with depth (Figures 1 and 2; Welch one-way ANOVA, all $P<0.0001)$. Soluble cation concentrations, other than $\mathrm{Ni}, \mathrm{Co}, \mathrm{Cu}$ and $\mathrm{Pb}$, individually or summed, also changed with depth (Figures 1-4; Welch one-way ANOVA, all $P<0.003$ ). For the total concentrations in the bog peat, two distinct patterns were observed. Total $\mathrm{Na}$ and $\mathrm{Mg}$ (Figure 1) formed "D" shaped profiles (Shotyk, 1988), with concentrations being lower at 0-0.5 $\mathrm{m}$ than at 2.5-3 $\mathrm{m}$ (Tamhane all $P<0.0001$ ). Total $\mathrm{Ca}$ (Figure 1c) $\mathrm{Mn}, \mathrm{Fe}, \mathrm{Ni}, \mathrm{Co}$, and $\mathrm{Cu}$ (Figure 2a-e) and $\mathrm{Al}$ (Figure 3) presented a "C" shaped profile, with lower content at 3-3.5 m than at 0-0.5 m and >5 m (Tamhane all $P<0.025)$.

Very different patterns were observed for soluble concentrations of cations. In the Ellergower Moss peat, for Na, K Ca (Figure 1) and the sum of macronutrients (Figure 4), there were some significant differences between depths, but soluble concentrations remained fairly constant throughout the profile. There was no significant difference for the soluble $\mathrm{Zn}$ concentrations whereas total $\mathrm{Zn}$ at 0-05 m was significantly higher than at all the other depths (Tamhane, all $P<0.001$ ). Soluble $\mathrm{Mg}$ and Mn (Figures 1 and 2) decreased with depth (0-0.5 m to 1.5-2 m versus 2-2.5 $\mathrm{m}$ to $>5 \mathrm{~m}$ for $\mathrm{Mg}$, and 0-0.5 m versus $1-1.5 \mathrm{~m}$ to 4-4.5 m, Tamhane all $P<0.05)$. 


\section{Between site comparisons}

In between-site concentration comparisons of soluble cations, sums of soluble cations, total cations and sums of total cations differed between sites and depths with a significant sitexdepth interaction (all $P<0.05$ ). Some soluble cation concentrations were very low, which explains the high variability observed.

Macronutrients: Both soluble and total $\mathrm{Na}$ in Cothill, especially at 0-0.5 m, was higher than for Snelsmore and Ellergower Moss (Tukey all $P<0.005$ ), and higher for Snelsmore than Ellergower Moss (Figure 1; Tukey all $P<0.005$ ). At each depth, soluble $\mathrm{Mg}$ in Ellergower Moss was at least 4 times lower than in the other two sites (Figure 1; Tukey all $P<0.0002)$. However, total $\mathrm{Mg}$ was measured in higher concentrations for all depths at Ellergower Moss peat than in the other two sites (Figure 1). Soluble and total Ca was about 80 and 200 times higher in Cothill than in Snelsmore and Ellergower Moss respectively, and higher in Snelsmore than in Ellergower Moss (Tukey all $P<0.05$; Figure 5).

Micronutrients: At 0-0.5 m, soluble Mn was about 10 times higher in Snelsmore peat than in peat from the other sites (Figure 2, Tukey all $P<0.002$ ), whereas total Mn was the highest in Cothill peat (about 2 to 10 times higher, all $P<0.05$, Figure 2). For $\mathrm{Fe}, \mathrm{Ni}, \mathrm{Co}$ and $\mathrm{Zn}$ (Figure 2), highest soluble and total concentrations were measured in Snelsmore peat. Soluble Al (Figure 3) was between 10 and 140 times higher in Snelsmore peat (Tukey all $P<0.003)$

Sum of micro- and macronutrients: At all depths, the sum of soluble and total macronutrients ( $\mathrm{K}, \mathrm{Na}, \mathrm{Mg}$ and $\mathrm{Ca}$ ) was higher in Cothill than in the other two sites (Tukey 
all $P<0.05$; Figure 4). The sum of soluble macronutrients was higher in Snelsmore than in Ellergower Moss, especially at the surface, but the difference in terms of total content was much lower or even not significant. At all depths, the sum of soluble micronutrients (Mn, $\mathrm{Fe}, \mathrm{Co}, \mathrm{Ni}, \mathrm{Cu}$ and $\mathrm{Zn}$ ) was between 3 to 32 times higher in Snelsmore than in the other sites (Figure 4; Tukey all $P<0.05$ ). However, the sums of total micronutrients in Cothill and Snelsmore peat at 0-0.5 m (Figure 4) were not significantly different $(P>0.05)$. Both sums of soluble and total micronutrients were lower in Ellergower Moss than in the other sites (Figure 4).

\section{Water / Ammonium Acetate quotient}

Quotients for $\mathrm{Na}$ and $\mathrm{Mg}$ (Figure 5) differed between sites and the interaction with depth was significant (ART ANOVA; all $P<0.05$ ). These cations are strongly adsorbed through exchange reactions in Ellergower Moss surface peat compared to the two other sites with the quotients of soluble to exchangeable cation for $\mathrm{Na}$ and $\mathrm{Mg}$ being lower in Ellergower Moss peat than elsewhere (Figure 5; Tukey all $P<0.02)$. In deeper peat $(1-1.5 \mathrm{~m}$ and $>1.5$ m) however, the quotients were higher for Cothill than either Snelsmore or Ellergower Moss (Tukey all $P<0.05$ ). Quotients for $\mathrm{Na}$ and $\mathrm{Mg}$ at the surface of Ellergower Moss were significantly higher than deeper than 2.5-3 $\mathrm{m}$ to $>5 \mathrm{~m}$ (Tamhane all $P<0.05$ ).

\section{Cation Exchange Capacity and Exchange Site Saturation Level}

At each depth, the CEC in bog peat was higher than at the other sites (Table 1). For Cothill peat, CEC increased with depth, whereas it decreased in Snelsmore peat. In Ellergower Moss peat, the CEC decreased with depth until 1-1.5 m, and then increased to reach

maximum values at 4-4.5 m (Table 1). For both Cothill and Snelsmore, CEC was correlated to organic matter content (both sites pooled $\mathrm{r}=0.95, P<0.05$ ). 
Cothill peat was saturated by cations (Exchange Sites Saturation Level quotients $>1$, Figure 6). Because the quotient was already high with the ammonium acetate estimate, the quotient using nitric acid is not displayed. Furthermore, at $\mathrm{pH}>6$ in Cothill peat nitric acid may dissolve cations that are in chemical forms other than ionically bound to exchange sites and therefore any quotient may not necessarily reflect the degree of saturation of exchange sites. Both ammonium acetate and nitric acid quotient estimates were $<1$ in Ellergower Moss (Figure 6) indicating unsaturated peat. The ammonium acetate derived quotient was $<1$ for Snelsmore peat but the nitric acid derived quotients was $>1$ (Figure 6).

\section{Discussion and conclusion}

We have found that the totals and ratios of total, extractable, exchangeable and soluble cations, cation exchange capacity and exchange site saturation levels differ with depth through peat profiles and differ between peat from an acid bog, a mesotrophic calcareous fen and a transitional valley mire. Although between site differences are not surprising, cross-site comparisons can be used to elucidate control mechanisms. Within site (depth) differences may also indicate that cation-related limits to microbial activity may differ within a peat profile.

Concentrations of cations in bog peat were compared to the two fen sites. At all depths, the sum of soluble and total macronutrients ( $\mathrm{K}, \mathrm{Na}, \mathrm{Mg}$ and $\mathrm{Ca}$ ) was higher in Cothill than in the other two sites, because of the high $\mathrm{Ca}$ concentrations. The sum of soluble macronutrients was higher in Snelsmore than in Ellergower Moss, especially at the surface, but the difference in terms of total content was either lower or not significantly different. At all depths, the sum of soluble micronutrients (Mn, Fe, $\mathrm{Co}, \mathrm{Ni}, \mathrm{Cu}$ and $\mathrm{Zn}$ ) was between 3 to 32 times higher and Al was between 10 and 140 times higher in Snelsmore 
than in the other two sites. These micronutrients were possibly high in Snelsmore peat due to the surrounding area being used as an ammunition dump during the Second World War (West Berkshire Council, 2006; Evans, 2006). However, the sums of total micronutrients in Cothill and Snelsmore peat at 0-0.5 m were not significantly different. Both sums of soluble and total micronutrients were lower in the bog peat than in the fen peats. Soluble $\mathrm{Mg}$ in the bog was at least 4 times lower than in the fens but total $\mathrm{Mg}$ was measured in higher concentrations in Ellergower Moss peat due to its proximity to the sea and being exclusively rain-fed.

Total cation concentrations varied between sites and with depth at each site. This variation can be explained by site geomorphology, current internal and external processes and historical factors. $\mathrm{Mg}$ concentrations were greater than those of $\mathrm{Ca}$ at all depths in Ellergower Moss peat but $\mathrm{Ca}$ tended to increase towards the bottom of the profile and $\mathrm{Mg}$ tended to decrease, indicating a groundwater effect at the start of peat formation and dominance of rainfall as peat accumulates. For Cothill and Snelsmore, Ca concentrations were higher than $\mathrm{Mg}$ concentrations throughout, indicating the dominance of groundwater in these shallower peats within basins.

Total Mn, Co, Zn, Fe, Ni and $\mathrm{Cu}$ concentrations profiles from Ellergower Moss had C shapes typical of those described in the literature (e.g. Mattson and Koutler-Andersson, 1955; Shotyk, 1988; Hill and Siegel, 1991). The upward decrease in the profiles for all these cations from the bottom can be explained by the progressive independence of the system from the ground water as peat accumulates. The high concentrations at the bottom may also indicate a continuing influence of mineral-rich water at the base of the bog, though this can only be resolved by hydrological study. The increase in Ellergower Moss of soluble Co and Ni with depth may be explained by weathering over time (Schlesinger, 
1997; Kelly et al., 1998). Anthropogenic input, mineral uptake and plant/decomposer cycling are likely to dominate at the surface.

$\mathrm{Cu}, \mathrm{Pb}$ and $\mathrm{Zn}$ surface concentrations from ash and dry peat acid extractions are even higher than the bottom concentrations. Peat profiles act as archives for a wide variety of atmospheric constituents (Clymo et al., 1990; Shotyk, 1995). Anthropogenic releases of $\mathrm{Pb}, \mathrm{Cu}, \mathrm{Zn}$ and other metals are greater than from natural sources (Benjamin and Honeyman, 1994; Zaccone et al, 2007a) and produce heavy metal enrichment in peatlands through long-range transport (Mattson and Koutler-Anderson, 1955; Livett et al., 1979; Santelmann and Gorham, 1988; Zoltai, 1988; Steinnes, 1997). This may explain some of the upper part of the "C" shaped profiles. The high capacity of Ellergower Moss peat to conserve anthropogenic metallic cation inputs, through exchange reactions, could also explain why the total content of $\mathrm{Zn}$ and $\mathrm{Pb}$ are higher in Ellergower Moss than in Cothill.

Very different patterns were observed for soluble concentrations of cations with some significant differences between depths, but soluble concentrations remained fairly constant throughout the profile. High total cations do therefore not infer high soluble cations. The lack of correlation between the two may be due to variation in Exchange Site Saturation Levels and Cation Exchange Capacity.

At the surface, the quotients of soluble to exchangeable cation for $\mathrm{Na}$ and $\mathrm{Mg}$ were lower in bog peat than in the fen peats. This indicates that these cations are strongly adsorbed through exchange reactions in Ellergower Moss peat compared to the peat from the two fen sites. At each depth, the CEC in bog peat was higher than in peat from the other sites. Calculations of quotients of Exchange Sites Saturation Level (ESSL) indicate that Cothill peat was saturated by cations (quotient $>1$ ). By contrast, Ellergower Moss peat is unsaturated (quotient <1). From the quotient calculated using the ammonium acetate extraction, Snelsmore peat is not saturated throughout the profile. However, when nitric 
acid extractable cation concentrations are used, the peat is saturated at all depths. While this can be explained by the difference in $\mathrm{Al}$ concentrations yielded by the two types of extraction it also indicates that Snelsmore peat is saturated with a relatively large Al fraction.

Despite the highest total and exchangeable $\mathrm{Mg}$ concentrations among sites being measured in Ellergower Moss, soluble Mg was lowest in this site. Thus, in Ellergower Moss peat there was a greater negative charge compared to peat from the two fen sites (Miller and Donahue, 1990). Andersen et al. (1987) demonstrated with Sphagnum species that, when exchange sites are less saturated with $\mathrm{Mg}$, more heavy metals are adsorbed. Bunzl et al. (1976) demonstrated in Sphagnum peat that, when soluble cation concentrations are low, the cations are more adsorbed on exchange sites. The humification degree is important in determining which peat fraction binds the soluble cations. As the peat gets more and more humified with depth the proportion of many cations bound to humic acids increases downward a peat profile (Zaccone et al, 2007b). In Ellergower Moss, the peat is highly unsaturated by cations, as indicated by the Exchange Sites Saturation Level (ESSL), thus there are low concentrations of soluble cations. In the fen sites, ESSL were higher than in the bog. Exchange sites are probably completely saturated because of high $\mathrm{Ca}$ concentrations in Cothill and $\mathrm{Al}$ concentrations in Snelsmore. Because the peat is saturated with cations, the CEC in these sites is unlikely to reduce the amount of soluble cations. Soluble $\mathrm{Na}, \mathrm{Mg}, \mathrm{Mn}$ and Co concentrations were significantly positively correlated (Spearman correlation, all $P<0.05$ ) with ESSL (assessed with nitric acid). When the peat exchange sites are unsaturated (low ESSL), soluble cation concentrations are low. Thus, unsaturation of the Ellergower Moss peat explains why quotients were lower in the bog than in the fen sites and why Ellergower Moss was the poorest site in soluble $\mathrm{Mg}$ (despite high exchangeable concentrations of $\mathrm{Mg}$ ). 
It is known that Sphagnum (Clymo, 1963) and Sphagnum peat (Bunzl et al., 1976) have a high capacity to bind cations and this link is so strong that heavy metals such as $\mathrm{Pb}$ and $\mathrm{Al}$ are not necessarily exchangeable (ammonium acetate extractable). In addition, Bunzl (1974) showed that as peat becomes more saturated with $\mathrm{Pb}$, the exchange reaction rate decreases. As soon as $\mathrm{Zn}$ and $\mathrm{Pb}$ are released into the system (soluble) from the relatively high total pool of the surface, they are instantaneously adsorbed because of the increased strength of adsorption (low quotient) found at the surface. Within Sphagnum species, CEC depends on their relative position to the water table: species of wet habitats have a relatively low CEC, whereas hummock forming species have a higher CEC (Spearing, 1972; Hájec and Adamec, 2009). Thus, as the system changes from fen to bog, the Sphagnum community may change towards a community that has an overall higher adsorption capacity. In this succession, the low amount of soluble nutrients would be determined first by the increasing independence of the system to the local groundwater, but also by the increased adsorption of the Sphagnum community.

The bog, because of its ombrotrophic nature, has a low cation input (other than $\mathrm{Mg}$ ) and due to the high CEC of the peat this further decreases the soluble amount of nutrients. This supports Painter's (1991) view that bog peat has unsaturated exchange sites that binds cations to organic matter and may make them unavailable for microbial activity. However, microbes can release in the media exo-enzymes that would attack the organic matter and mobilize mineral nutrients (Sinsabaugh et al, 2009). These exo-enzymes can also be adsorbed onto exchange sites (Painter, 1995). This could occur especially in the bog where there was still a lot of exchange sites available to react with exo-enzymes (Figure 6). Such enzymatic inhibition is uspected to be of uttermost importance in the $\mathrm{C}$ storage in peat (Freeman et al, 2001) and peat exchange sites unsaturation could be a powerful tool to achieve such enzymatic inhibition. 
CEC may affect not only soluble cations, but also their total content by adsorbing cations and thus preventing losses through leaching. The $\mathrm{D}$ shape of total and exchangeable $\mathrm{K}, \mathrm{Na}$ and $\mathrm{Mg}$ profiles in the bog follows the overall shape of the organic matter content. Damman (1978) reported the same pattern for Mg from Scandinavian bogs. Malmer (1988) demonstrated that the CEC of Sphagnum, which dominate Ellergower Moss, determines the total concentrations of $\mathrm{Na}$ and $\mathrm{Mg}$. The capacity of Sphagnum species to retain macronutrient cations liberated from the decomposed peat combined with a loss of peat mass could explain the "D" shape distribution. Compared to the surface, at the bottom the CEC was lower, which would retain less Mg. This demonstrates the essential role of the CEC of the Sphagnum itself and the peat formed from the partial decay of Sphagnum on the distribution of these elements. The high CEC of Ellergower Moss is not entirely due to the presence of Sphagnum. The work here demonstrates that when expressed on a per organic matter basis the CECs of the different peats were very similar. However, the CEC of Ellergower Moss was high, simply because of the relatively high concentration of organic matter at this site compared to the other two.

We have demonstrated that at Ellergower moss, an undisturbed peat bog, CEC is an important factor in determining the size of each cation pool. With a high CEC, cations are not in solution due to the large number of free exchange sites. They may be more available at the other sites due to a lack of availability of exchange sites. The exchange sites of Snelsmore peat are saturated by macro- and micronutrient cations and such a "mopping up" of cations is unlikely. Al is a determinant cation affecting the ESSL: because this element is probably in its $\mathrm{Al}^{3+}$ form (acidic conditions), it may occupy many exchange sites. Overall, the highest soluble cation concentrations were found at Snelsmore and Cothill. However, as peat is building in Snelsmore, the CEC will be increasing at the surface and the exchange sites may becomes less and less saturated. One can note that the 
exchange capacity of Sphagnum peat, in contrary to Carex peat, is less sensitive to varying pH, at least for $\mathrm{Cu}$ (Ringqvist and Öborn, 2002). As the peat water becomes more acidic with peatland development, the exchange capacity of Sphagnum peat would not decrease, in contrary to Carex peat, and would keep along the succession from fen to bog the same capacity to bind cations indifferently from the $\mathrm{pH}$. This would asure the high exchange capacity of Sphagnum peat, and hence the high ESSL, even at very low pH. As peat becomes unsaturated, exo-enzymes are likely to be more and more inhibited. If CEC does decrease the availability of cations, through both strong binding and inhibition of exoenzymes activity, a positive feedback may exist which reduces microbial activity through decrease of available nutrients, which in turn increases overall CEC as the organic fraction increases. If this is the case then a sudden change in the rate of peat accumulation may occur. This change may be reinforced by Sphagnum, which grows in low nutrient conditions and has a high number of exchange sites when both living and dead. For other plant species (like Phragmites), it is only the peat derived from them that has a high number of exchange sites (Moorhead et al., 2000). We suggest that the changes of soluble cation concentrations at the bottom of the Ellergower Moss profile demonstrate this sudden transition from one state to another. In Cothill, the high concentration of Ca saturates all the exchange sites, leading them to play only a minor role in the distribution of cations.

There are few studies in the literature on the availability of cations in peat (Williams and Crawford, 1984; Thomas and Pearce, 2004) and none on the effect of $\mathrm{Pb}$ or Al. We demonstrate that patterns of soluble and total cations are not equivalent. This may lead to misinterpretations in the literature with some authors using soluble and others total cation concentrations when interpreting microbial mineral nutrition studies. There is a need to determine which cation fraction is available to microbes in other studies to fully understand microbial activity and care needs to be taken in cross site comparisons. 
Although only one site of each type of peatland was studied here, they were representative of their own type. However, this study encourages similar investigations on different types of peatlands to confirm the conclusions. This study also encourages to study enzymatic activity in relation to exchange site saturation, as large amount of available sites may have an inhibitory effect that would enhance the lack of soluble cations by preventing mineralization. We further demonstrate that CEC is more closely related to organic matter content than Sphagnum per se.

\section{Acknowledgment}

This work was funded by Oxford Brookes University. We thank English Nature (now Natural England), Scottish Natural Heritage and Forest Enterprise Scotland (South) for allowing access to the sites and sampling of peat. We thank Dr Mike Fowler for helping with the ICPAES. 


\section{References}

Andersen, K., Grasdalen, H., Holsen, K. A. and Painter, T. J., 1987. Structure, properties, and potential applications of Sphagnum holocellulose. In: S.S. Stivala, V. Crescenzi and I.C.M. Dea (Editors), Industrial Polysaccharides: the impact of biotechnology and advanced methodologies. Gordon and Breach, New York, pp. 15-34.

Basiliko, N. and Yavitt, J. B., 2001. Influence of $\mathrm{Ni}, \mathrm{Co}, \mathrm{Fe}$ and $\mathrm{Na}$ additions on $\mathrm{CH}_{4}$ production in Sphagnum-dominated Northern American peatlands. Biogeochemistry, 52: 133-153.

Benjamin, M. M. and Honeyman, B. D., 1994. Trace metals. In: S. S. Butcher, R. J. Charlson, G. H. Orians and G. V. Wolfe (Editors), Global Biogeochemical Cycles. Academic Press, London, pp. 317-352.

Bunzl, K., 1974. Kinetics of ion exchange in soil organic matter. II. Ion exchange during continuous addition of $\mathrm{Pb}^{2+}$ ions to humic acid and peat. Journal of Soil Science, 25: 32-41.

Bunzl, K. Schmidt, W. and Sansoni, B., 1976. Kinetics of ion exchange in soil organic matter. IV. Adsorption and desorption of $\mathrm{Pb}^{2+}, \mathrm{Cu}^{2+}, \mathrm{Cd}^{2+}, \mathrm{Zn}^{2+}$ and $\mathrm{Ca}^{2+}$ by peat. Journal of Soil Science, 27: 32-41.

Chapin III, F. S., Matson, P. A. and Mooney, H. A., 2002. Principles of terrestrial ecosystem ecology. Springer Verlag, New York.

Clymo, R. S., 1963. Ion exchange in Sphagnum and its relation to bog ecology. Annals of Botany, 27: 309-324.

Clymo, R. S., 1983. Peat. In: A. J. P. Gore (Editor), Ecosystems of the World, vol. 4A. Mires: Swamp, Bog, Fen and Moor. Elsvier, Amsterdam, pp. 159-224. 
Clymo, R. S., Oldfield, F., Appleby, P. G., Pearson, G. W., Ratnesar, P. and Richardson, N., 1990. The record of atmospheric deposition on a rainwater-dependent peatland. Philosophical Transactions of the Royal Society, London, B327: 331-338.

Coulson, J. C. and Butterfield, J., 1978. An investigation of the biotic factors determining the rates of plant decomposition on blanket bog. Journal of Ecology, 66: 631-650.

Damman, A. W. H., 1978. Distribution and movement of elements in ombrotrophic peat bogs. Oikos, 30: 480-495.

Dise, N. B. and Verry, E. S., 2001. Suppression of peatland methane emission by cumulative sulfate deposition in simulated acid rain. Biogeochemistry, 53: 143-160.

Evans, N. F., 2006. British artillery in World War 2. Retrieved on October 2006 from http://members.tripod.com/ nigelef/ammo.htm.

Freeman, C., Ostle, N. and Kang, H, 2001._An enzymic "latch" on a global carbon store. Nature, 409: 149.

Gonzalez-Gil, G., Kleerebezem, R. and Lettinga, G., 1999. Effects of nickel and cobalt on kinetics of methanol conversion by methanogenic sludge as assessed by on-line monitoring. Applied and Environmental Microbiology, 65: 1789-1793.

Gore, A. J. P. and Allen, S. E., 1956. Measurement of exchangeable and total cation content for $\mathrm{H}^{+}, \mathrm{Na}^{+}, \mathrm{K}^{+}, \mathrm{Mg}^{2+}, \mathrm{Ca}^{2+}$ and iron, in high level blanket peat. Oikos, 7: $48-55$.

Hájek, T. and Adamec, L., 2009. Mineral nutrient economy in competing species of Sphagnum mosses. Ecological Research, 24: 291-302.

Hall-Stoodley, L., Costerton, J. W. and Stoodley, P., 2004. Bacterial biofilms: from the natural environment to infectious diseases. Nature, 2: 95-108.

Hill, B. M. and Siegel, D. I., 1991. Groundwater flow and the metal content of peat. Journal of Hydrology, 123: 211-224. 
Jowsey, P. C., 1966. An improved peat sampler. New Phytologist, 65: 245-248.

Karam, A., 1993. Chapter 44: Chemical properties of organic soils. In: M. R. Carter (Editor), Soil Sampling and Methods of Analysis, Canadian Society of Soil Science. Lewis Publishers, pp. 459-471.

Kelly, E. F., Chadwick, O. A. and Hilinski, T. E., 1998. The effect of plants on mineral weathering. Biogeochemistry, 42: 21-53.

Kyziol, J., 2002. Effect of physical properties and Cation Exchange Capacity on sorption of heavy metals onto peats. Polish Journal of Environmental Studies, 11: 713-718.

Livett, E. A., Lee, J. A. and Tallis, J. H., 1979. Lead, zinc, and copper analyses of British blanket peats. Journal of Ecology, 67: 865-891.

Malmer, N., 1988. Patterns in the growth and the accumulation of inorganic constituents in the Sphagnum cover on ombrotrophic bogs in Scandinavia. Oikos, 53: 105-120.

Martin, N. J. and Holding, A. J., 1978. Nutrient availability and other factors limiting microbial activity in the blanket peat. In: O. W. Heal and D. F. Perkins (Editors), The ecology of British moors and mountain grassland. Springer Verlag, New York, pp. 113-135.

Mattson, S. and Koutler-Andersson, E., 1955. Geochemistry of a Raised Bog. Annals of the Royal Agricultural College of Sweden, 21: 321-366.

Miller, R. W. and Donahue, R. L., 1990. Soils, an introduction to soils and plants growth. Prentice-Hall International Editions, USA.

Moorhead, K. K., Moynihan, R. E. and Simpson, S. L., 2000. Soil characteristics of four southern Appalachian fens in North Carolina, USA. Wetlands, 20: 560-564.

Painter, T. J., 1991. Lindow man, Tollund man and other peat-bog bodies: the preservative and antimicrobial action of sphagnan, a reactive glycuronoglycan with tanning and sequestering properties. Carbohydrate Polymers, 15: 123-142. 
Painter, T. J., 1995. Chemical and microbiological aspects of the preservation processes in Sphagnum peat. In: R. C. Turner and R. G. Scaife (Editors), Bog Bodies - New discoveries and new Perspectives. British Museum Press, London, pp. 88-100.

Puustjärvi, V., 1956. On the cation exchange capacity of peats and on factors of influence upon its formation. Acta Agriculturae Scandinavica, 6: 410-449.

Richter, S. J. and Payton, M. E., 1999. Nearly exact tests in factorial experiments using the aligned rank transform. Journal of Applied Statistics, 26: 203-217.

Ringqvist, L and Öborn, I., 2002. Copper and Zinc adsorption onto poorly humified Sphagnum and Carex peat. Water Research. 36: 2233-2242.

Santelmann, M. V. and Gorham, E., 1988. The influence of airborne road dust on the chemistry of Sphagnum mosses. Journal of Ecology, 76: 1219-1231.

Schlesinger, W. H., 1997. Biogeochemistry: an analysis of global change. Academic Press, San Diego.

Shotyk, W., 1988. Review of the inorganic chemistry of peats and peatlands waters. Earth Science Reviews, 25: 95-176.

Shotyk, W., 1995. Peat bog archives of atmospheric metal deposition: geochemical evaluation of peat profiles, natural variations in metal concentrations and metal enrichment factors. Environmental Review, 4: 149-183.

Singsabaugh, R. L., Hill, B. H.and Follstad Shah J. J., 2009. Ecoenzymatic stoichiometry of microbial organic nutrient acquisition in soil and sediment. Nature, 462:795-798.

Spearing, A. M., 1972. Cation-exchange capacity and galacturonic acid content of several species of Sphagnum in Sandy Ridge bog, central New York State, Bryologist, 75: 154-158.

SPSS, Inc., 2004. SPSS for Windows Version 13.0. Chicago Illinois, SPSS Inc. 
Statsoft, Inc., 2001. STATISTICA for Windows Version 6.0. Tulsa Oklahoma, Statsoft, Inc.

Steinnes, E., 1997. Trace elements in ombrogenous peat profiles from Norway: Evidence of long-range atmospheric transport. Water and Air Soil Pollution, 100: 405-413.

Summer, M. E., Fey, M. V. and Noble, A. D., 1991. Nutrient status and toxicity problems in acid soils. In: B. Ulrich and M. E. Summer (Editors), Soil acidity. Springer Verlag, New York, pp. 149-182.

Teitzel, G. M. and Parsek, M. R., 2003. Heavy metal resistance of biofilm and planktonic Pseudomonas aeruginosa. Applied and Environmental Microbiology, 69: 23132320.

Thomas, P. A. and Pearce, D. M. E., 2004. Role of cation exchange in preventing the decay of anoxic deep bog peat. Soil Biology and Biochemistry, 36: 23-32.

Tummavuori, J. and Aho, M., 1980. On the ion-exchange properties of peat part I: on the adsorption of some divalent metal ions $\left(\mathrm{Mn}^{2+}, \mathrm{Co}^{2+}, \mathrm{Ni}^{2+}, \mathrm{Cu}^{2+}, \mathrm{Zn}^{2+}, \mathrm{Cd}^{2+}\right.$ and $\left.\mathrm{Pb}^{2+}\right)$ on the peat. Suo, 2-3: 45-51.

University of Minnesota, 2000. Research Analytical Laboratory. Retrieved on January 2002 from http://ral.coafes.umn.edu/soil.htm.

Ure, A.M., 1991. Methods of analysis for heavy metals in soils. In: B.J. Alloway (Editor), Heavy metals in soils. Blackie Academic and Professional, London, pp. 58-104.

Waughman, G. J., 1980. Chemical aspects of the ecology of some south German peatlands. Journal of Ecology, 68: 1025-1046.

West Berkshire Council, 2006. Snelsmore common. Retrieved on October 2006 from http://www.westberks.gov.uk/media/doc/1/5/Snelsmore_Common.doc.

Williams, R. T. and Crawford, R. L., 1984. Methane production in Minnesota peatland. Applied and Environmental Microbiology, 29: 1266-1271. 
Yavitt, J. B., Williams, C. J. and Wieder, R. K., 2005. Soil chemistry versus environmental controls on production of $\mathrm{CH}_{4}$ and $\mathrm{CO}_{2}$ in northern peatlands. European Journal of Soil Science, 56: 169-178.

Zacone, C., Cocozza, C., Cheburkin, A. K., Shotyk, W. and Miano, T. M., 2007a. Highly organic soils as "witnesses" of anthropogenic $\mathrm{Pb}, \mathrm{Cu}, \mathrm{Zn}$ and $137 \mathrm{Cs}$ inputs during centuries. Water, Air and Soil Pollution, 186: 263-271.

Zacone, C., Cocozza, C., Cheburkin, A. K., Shotyk, W. and Miano, T. M., 2007b. Enrichment and depletion of major and trace elements, and radionuclides in ombrotrophic raw peat and corresponding humic acids. Geoderma, 141: 235-246.

Zoltai, S.C., 1988. Distribution of base metals in peat near a smelter at Flin Flon, Manitoba. Water, Air, and Soil Pollution, 37: 217-228. 


\section{TABLES}

Table 1. Organic matter content, CEC and $\mathrm{pH}$ (mean \pm s.e.) of peat from the three sites (Cothill, Snelsmore and Ellergower Moss).

\begin{tabular}{|c|c|c|c|c|c|c|c|c|}
\hline \multirow[b]{2}{*}{ Depth $(\mathrm{m})$} & \multicolumn{3}{|c|}{ OM content / \% of dry mass } & \multicolumn{3}{|c|}{$\mathrm{CEC} / \mathrm{cmol} \mathrm{kg-1}$} & \multicolumn{2}{|r|}{$\mathrm{pH}$} \\
\hline & Cothill & Snelsmore & Ellergower & Cothill & Snelsmore & Ellergower & Cothill & Snelsmore \\
\hline $0.0-0.5$ & $36.0 \pm 0.8$ & $85.8 \pm 0.2$ & $97.4 \pm 0.1$ & $22.1 \pm 1.5$ & $68.1 \pm 0.8$ & $95.2 \pm 5.4$ & $6.5 \pm 0.1$ & $4.3 \pm 0.0$ \\
\hline $0.5-1.0$ & $43.5 \pm 0.7$ & $63.5 \pm 0.7$ & $98.3 \pm 0.1$ & $30.4 \pm 3.0$ & $45.2 \pm 1.2$ & $64.2 \pm 4.4$ & $6.5 \pm 0.1$ & $4.4 \pm 0.2$ \\
\hline $1.0-1.5$ & $55.6 \pm 0.6$ & $34.7 \pm 1.9$ & $98.2 \pm 0.0$ & $46.3 \pm 2.1$ & $28.3 \pm 2.9$ & $57.6 \pm 6.8$ & $6.4 \pm 0.1$ & $4.5 \pm 0.2$ \\
\hline $1.5-2.0$ & $62.9 \pm 0.3$ & $20.4 \pm 0.7$ & $98.3 \pm 0.0$ & $59.9 \pm 2.7$ & $10.4 \pm 1.2$ & $65.5 \pm 0.5$ & $5.3 \pm 0.0$ & $4.2 \pm 0.1$ \\
\hline $2.0-2.5$ & & & $97.7 \pm 0.1$ & & & $66.7 \pm 2.1$ & & \\
\hline $2.5-3.0$ & & & $98.4 \pm 0.0$ & & & $71.9 \pm 2.8$ & & \\
\hline $3.0-3.5$ & & & $98.7 \pm 0.0$ & & & $82.1 \pm 6.0$ & & \\
\hline $3.5-4.0$ & & & $98.6 \pm 0.1$ & & & $92.9 \pm 1.9$ & & \\
\hline $4.0-4.5$ & & & $98.3 \pm 0.1$ & & & $106.8 \pm 5.0$ & & \\
\hline $4.5-5.0$ & & & $98.2 \pm 0.1$ & & & $91.7 \pm 5.2$ & & \\
\hline$>5.0$ & & & $97.9 \pm 0.1$ & & & $93.8 \pm 1.2$ & & \\
\hline
\end{tabular}




\section{FIGURES CAPTIONS}

Figure 1 Profiles of median ( \pm min and max values) soluble and total macronutrients $(\mathrm{Na}$, $\mathrm{Mg}, \mathrm{K}, \mathrm{Ca})$ in Cothill $(\bullet)$, Snelsmore $(\square)$ and Ellergower Moss $(\boldsymbol{\Delta})(\mathrm{n}=4$ in all cases).

Figure 2 Profiles of median ( \pm min and max values) soluble and total micronutrients $(\mathrm{Mn}$, $\mathrm{Fe}, \mathrm{Ni}, \mathrm{Co}, \mathrm{Cu}, \mathrm{Zn})$ in Cothill ( $\bullet)$, Snelsmore ( $\square)$ and Ellergower Moss ( $\mathbf{\Delta})(\mathrm{n}=4$ in all cases).

Figure 3 Profiles of median soluble and total $\mathrm{Pb}$ and $\mathrm{Al}$ ( \pm min and max values) in Cothill $(\diamond)$, Snelsmore $(\square)$ and Ellergower Moss $(\boldsymbol{\Delta})(\mathrm{n}=4$ in all cases).

Figure 4 Profiles of median soluble and total sum of micronutrients and macronutrients $( \pm$ min and max values) in Cothill ( $\bullet)$, Snelsmore ( $\square$ ) and Ellergower Moss $(\boldsymbol{\Delta})$ (n $=4$ in all cases).

Figure 5 Quotient of water soluble to ammonium acetate exchangeable $\mathrm{Na}$ and $\mathrm{Mg}$ concentrations ( \pm min and max values) in Cothill ( $\bullet$ ), Snelsmore ( $\square$ ) and Ellergower Moss ( $\Delta)(n=4$ in all cases $)$.

Figure 6 Exchange Site Saturation Level by cations as express by the quotient of the sum of charges extracted with ammonium acetate ( $)$ or nitric acid ( $\square$ ) on CEC. 
FIGURES 


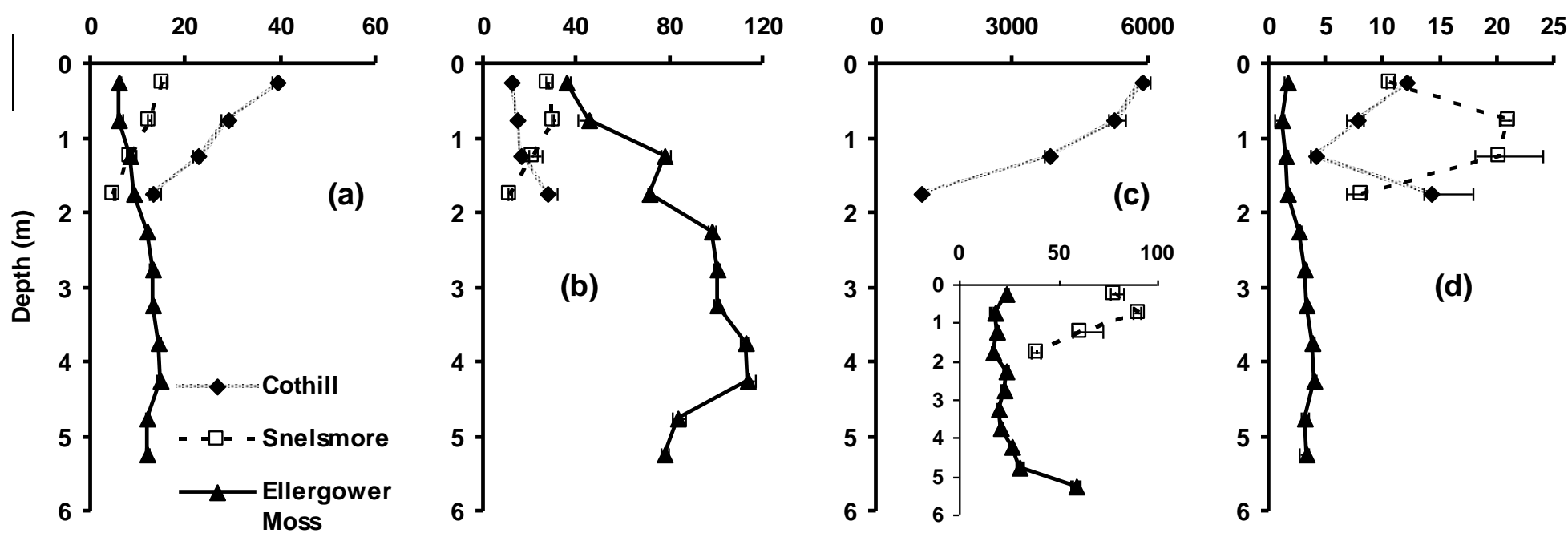

[total] ( $\mu \mathrm{mol} \mathrm{g}^{-1}$ Dry weight)

[soluble] ( $\mu \mathrm{mol} \mathrm{g}{ }^{-1}$ OM weight)
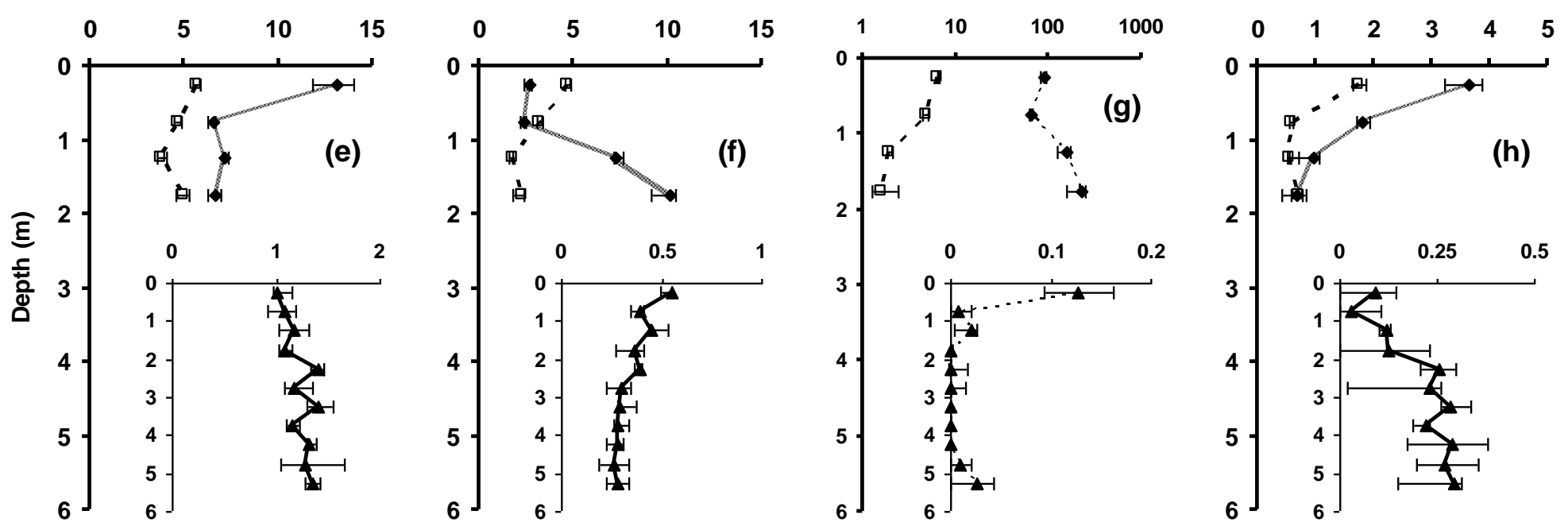

Figure 1. 

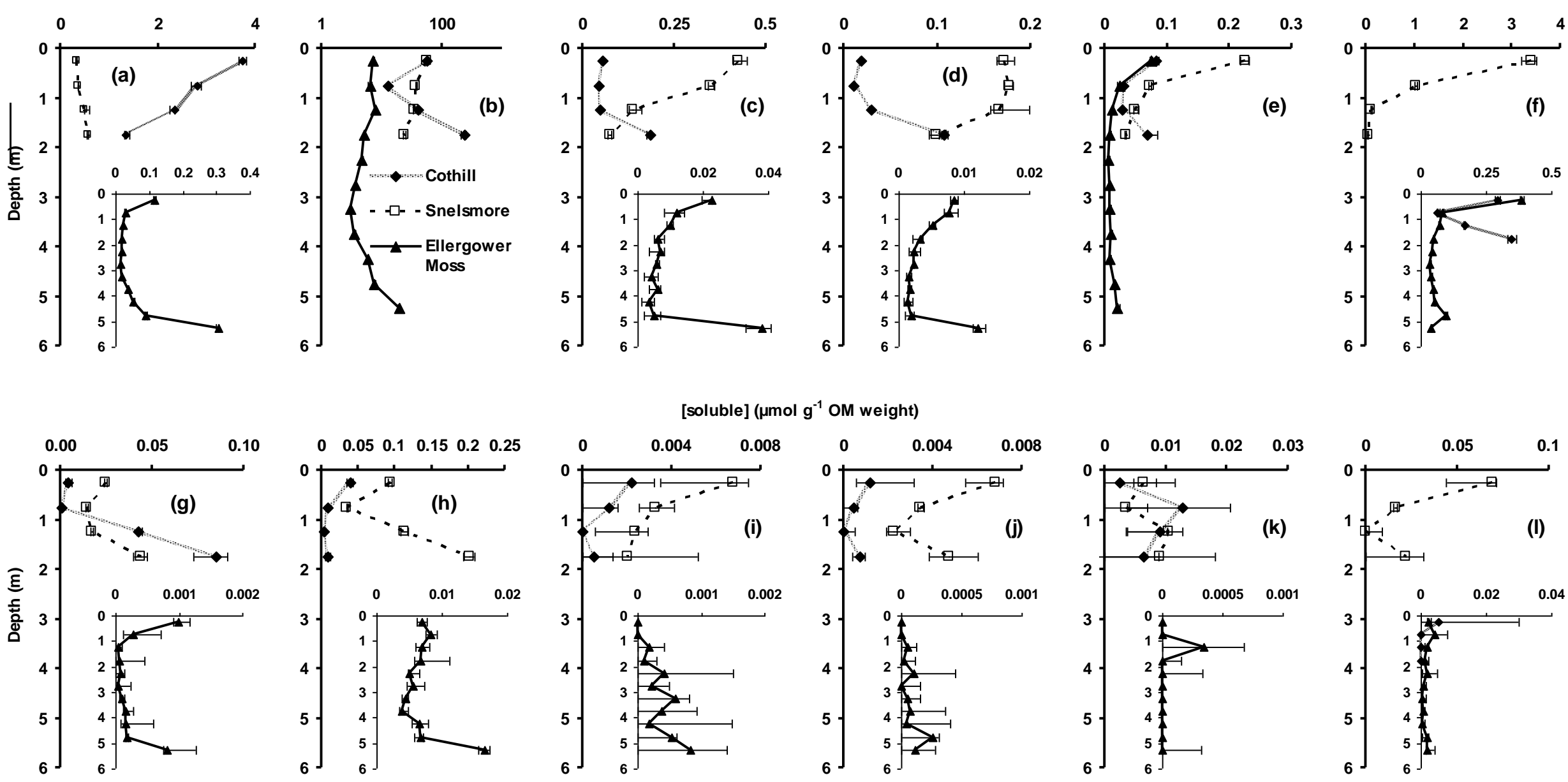

Figure 2. 
[AI] [Pb]

[total] ( $\mu \mathrm{mol} \mathrm{g} \mathrm{g}^{-1}$ Dry weight)

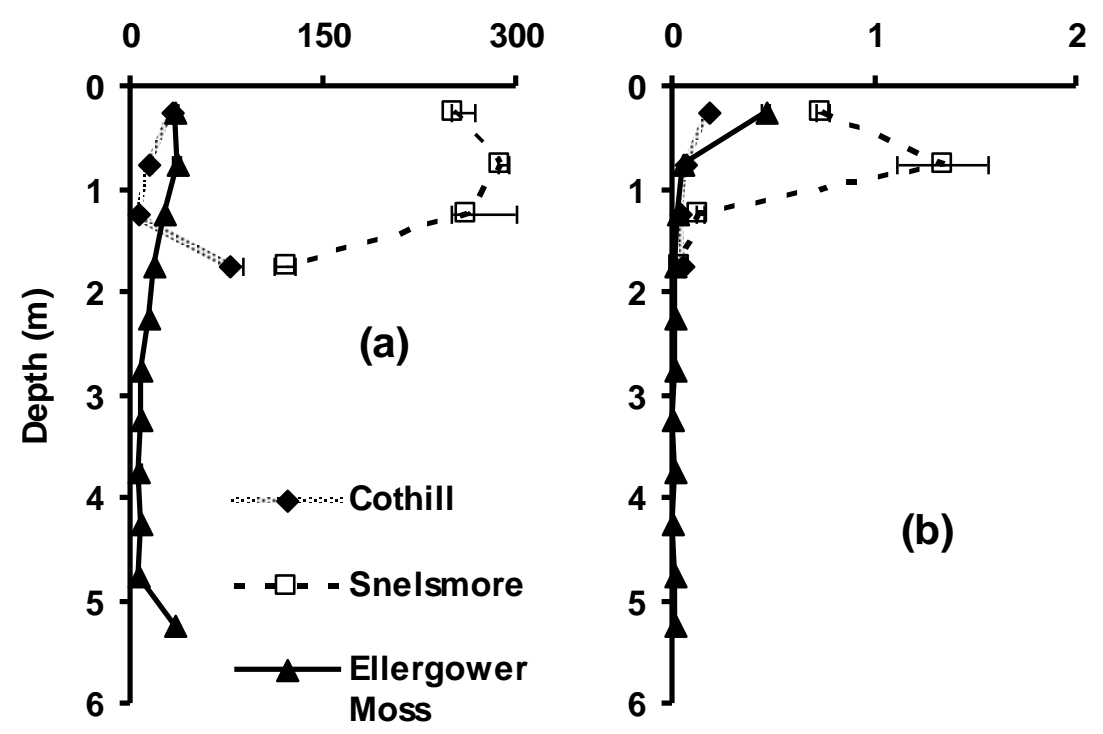

[soluble] ( $\mu \mathrm{mol} \mathrm{g}{ }^{-1}$ OM weight)

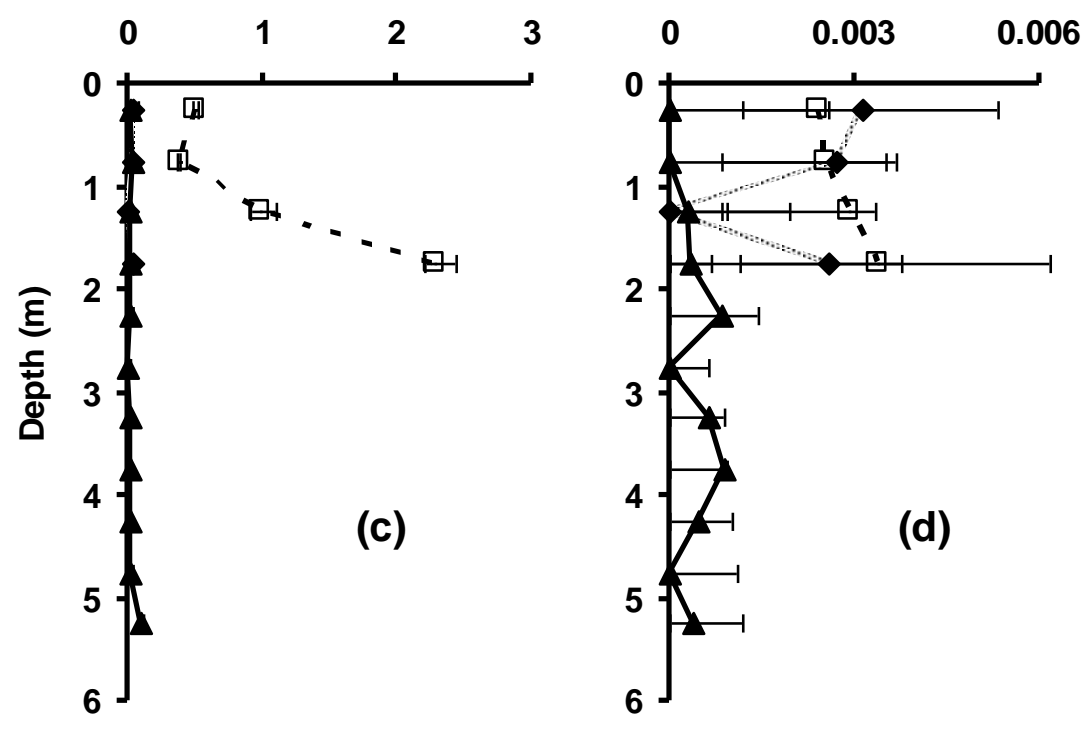

Figure 3. 


\section{[sum macronutrients] [sum micronutrients]}

[total] ( $\mu \mathrm{mol} \mathrm{g} \mathrm{g}^{-1}$ Dry weight)

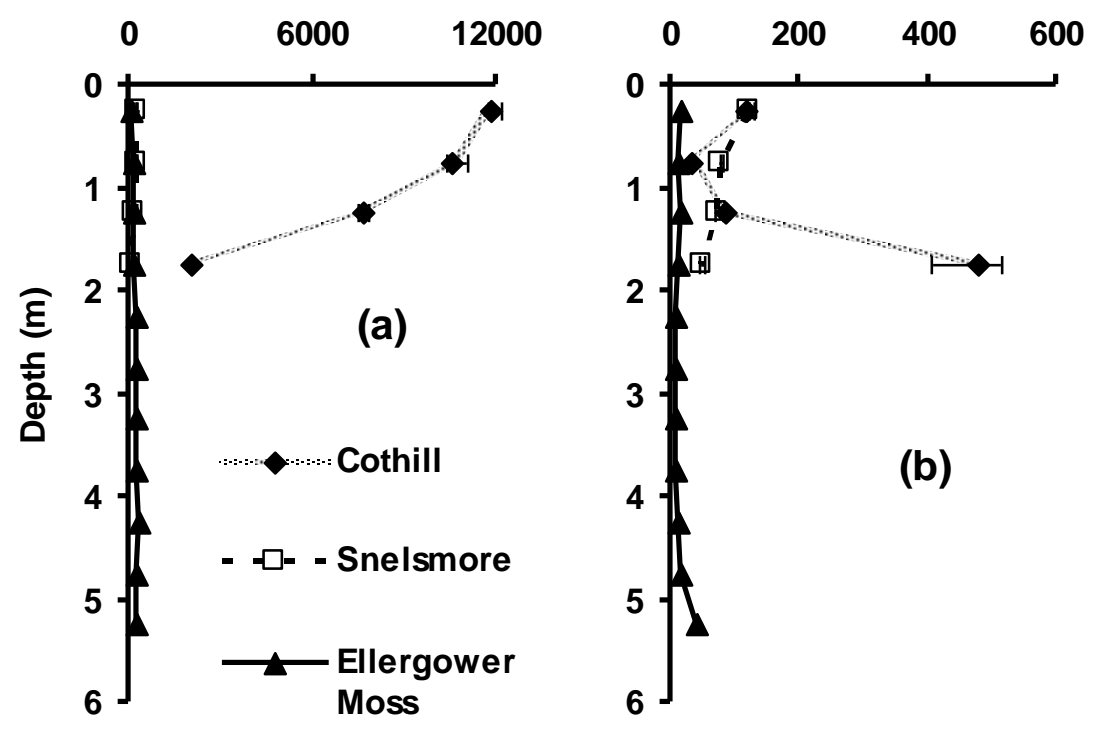

[soluble] ( $\mu \mathrm{mol} \mathrm{g}{ }^{-1}$ OM weight)
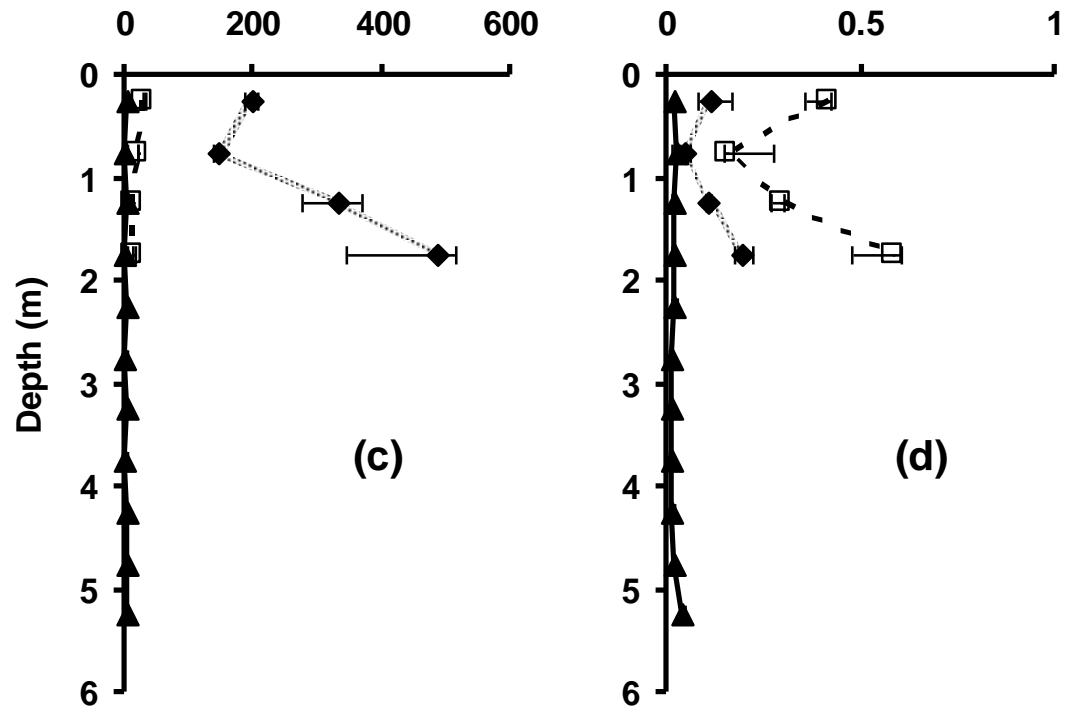

Figure 4. 

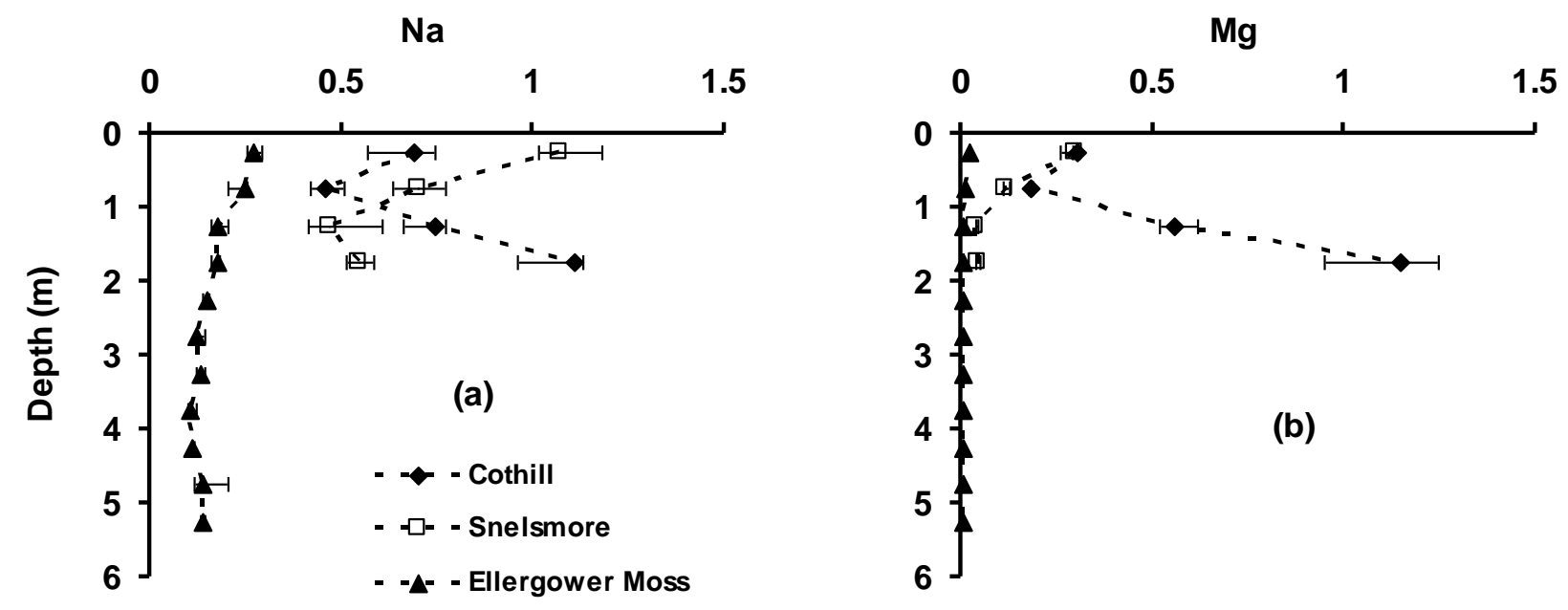

Figure 5. 


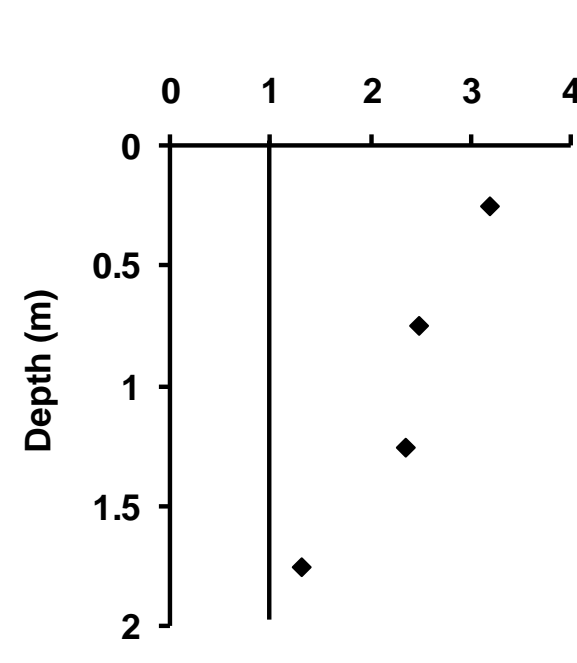

(a) Cothill

Quotient of saturation

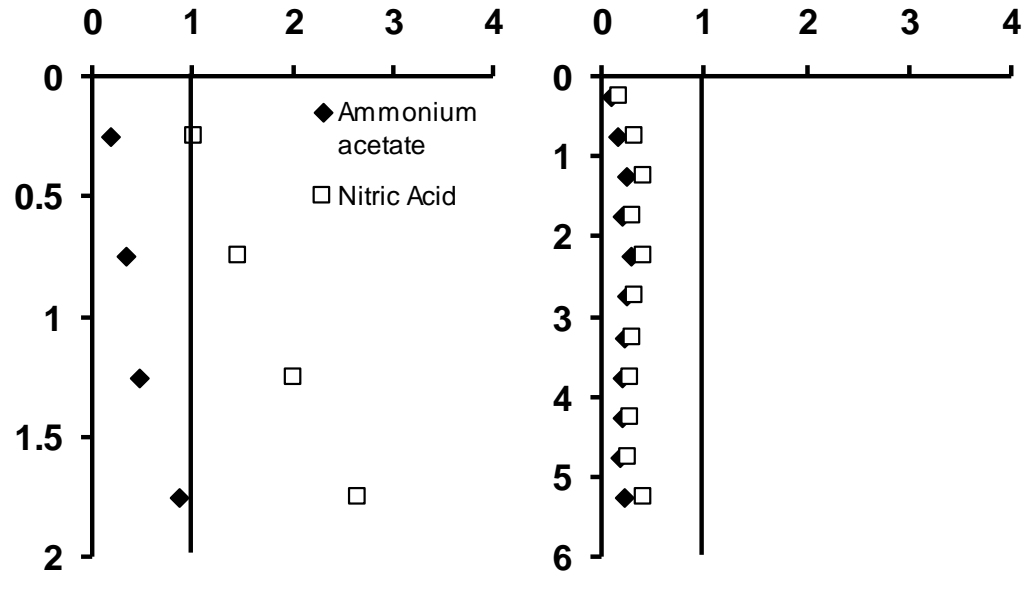

(b) Snelsmore

(c) Ellergower Moss

Figure 6. 